\title{
Review \\ Review of Studies on Joint Recovery of Macroalgae and Marine Debris by Hydrothermal Liquefaction
}

\author{
Yuliya Kulikova ${ }^{1,2, *}$, Stanislav Sukhikh ${ }^{1}$, Svetlana Ivanova ${ }^{3,4, *} \mathbb{C}$, Olga Babich $^{1} \mathbb{D}$ and Natalia Sliusar ${ }^{5}$ \\ 1 Institute of Living Systems, Immanuel Kant BFU, 236016 Kaliningrad, Russia; stas-asp@mail.ru (S.S.); \\ olich.43@mail.ru (O.B.) \\ 2 Institute of Engineering and Environmental Safety, Togliatti State University, 445000 Togliatti, Russia \\ 3 Natural Nutraceutical Biotesting Laboratory, Kemerovo State University, Krasnaya Street 6, \\ 650043 Kemerovo, Russia \\ 4 Department of General Mathematics and Informatics, Kemerovo State University, Krasnaya Street 6, \\ 650043 Kemerovo, Russia \\ 5 Environmental Protection Department, Perm National Research Polytechnic University, 614000 Perm, Russia; \\ post@kantiana.ru \\ * Correspondence: kulikova.pnipu@gmail.com (Y.K.); pavvm2000@mail.ru (S.I.); Tel.: +7-912-784-9858 (Y.K.); \\ +7-384-239-6832 (S.I.)
}

Citation: Kulikova, Y.; Sukhikh, S.; Ivanova, S.; Babich, O.; Sliusar, N. Review of Studies on Joint Recovery of Macroalgae and Marine Debris by Hydrothermal Liquefaction. Appl. Sci. 2022, 12, 569. https://doi.org/ 10.3390/app12020569

Academic Editor:

Alessandro Acquavita

Received: 6 November 2021

Accepted: 4 January 2022

Published: 7 January 2022

Publisher's Note: MDPI stays neutral with regard to jurisdictional claims in published maps and institutional affiliations.

Copyright: () 2022 by the authors Licensee MDPI, Basel, Switzerland. This article is an open access article distributed under the terms and conditions of the Creative Commons Attribution (CC BY) license (https:// creativecommons.org/licenses/by/ $4.0 /)$.

\begin{abstract}
At the moment, macroalgae blooms in sea waters, the rotting of which causes greenhouse gas emissions and contributes to the formation of a negative ecological and economic situation in coastal zones, which has become a serious problem. Fuel production through hydrothermal liquefaction (HTL) of macroalgae and marine debris is a promising solution to this ecological problem. The article provides an overview of studies on producing fuel from macroalgae and an assessment of the possibility of their joint recovery with marine debris. The optimal process conditions and their technological efficiency were evaluated. The article shows the feasibility of using heterogeneous catalysis and co-solvent to increase the yield of bio-oil and improve its quality. An assessment of the possibility of joint processing of waste macroalgae and marine debris showed the inexpediency of this direction. The high degree of drift macroalgae contamination also raises the question of the appropriateness of the preliminary extraction of other valuable components for nutrition use, such as fats, proteins, carbohydrates, and their derivatives.
\end{abstract}

Keywords: hydrothermal liquefaction; macroalgae; bio-oil; biomass; plastic; polymers; marine waste

\section{Introduction}

Nowadays bursts of macroalgae development have become a frequent occurrence and are associated with an increase in anthropogenic load on the hydrosphere objects and climate change. Objectively, there has been a three-fold increase in the number of recorded cases over the past 30 years [1]. Rotting algae becomes a source of greenhouse gases, creating a secondary anthropogenic load on the biosphere. The potential for the formation of greenhouse gases for algae is relatively high and amounts to $498.75 \mathrm{~mL}$ per $1 \mathrm{~g}$ of dry matter [2].

At the same time, the biomass of macroalgae has significant resource potential [3,4]. There are some articles on macroalgae processing with the production of bioethanol [5], biogas [6,7], biofuels [2,8,9] nutrients [10], and biologically active substances [11].

It should be noted that the processing of drifting macroalgae into fuel will allow for solving two problems of reducing the climatic load at once: namely, it will ensure the prevention of methane formation in the decay process and will make it possible to advance in solving the key problem of modern society-the reduction of $\mathrm{CO}_{2}$ emissions from the use of fossil fuels [12] and their replacement with carbon-neutral sources.

This article is focused on recycling drifting algae that washed ashore and has become, in fact, waste. Such algae, together with marine garbage, are collected from the beaches 
by special sieving machines and stored in heaps until they are taken to a landfill. The accumulation of such biomass varies significantly depending on the season and geography of the coast.

The problem of processing algae that has both drifted and washed ashore in order to produce fuel is due to their high moisture content, composition variability, seasonal fluctuations in volumes, and high degree of contamination with foreign impurities.

Technologies for direct conversion of biomass into liquid fuel can be conditionally divided into two groups: biochemical and thermochemical. The most suitable processing method depends on the amount and type of biomass, the desired form of energy produced, end-use requirements, environmental standards, and economic feasibility $[13,14]$.

The major problems associated with the biochemical production of biofuels from algae are low fuel yield (no more than 50\%) [15-17], the need for preliminary preparation of biomass, and the high cost of extracting target products $[18,19]$.

Direct thermochemical conversion of algae biomass into liquid fuel involves pyrolysis and hydrothermal liquefaction. The main problem of producing biofuel from biomass by pyrolysis is associated with the need to dry raw materials to a moisture content of no more than $10 \%$, which significantly worsens the technical, economic, and energy parameters of the process [20]. Due to the heterogeneity of raw materials, there is a risk of poisoning catalytic systems [21], and the fuel yield does not exceed 30\%.

Hydrothermal liquefaction (HTL) refers to a thermochemical process in which biomass and organic waste are decomposed by the action of supercritical (i.e., the water pressure and temperature are above the critical point of $374{ }^{\circ} \mathrm{C}$ and $22.1 \mathrm{MPa}$ ) or subcritical water (i.e., when the water temperature is significantly below the critical point). Under such conditions, water possesses certain unique properties. For example, near the critical point, the dissociation constant of water increases sharply, forcing water to act as an acidic or basic catalyst for numerous reactions which makes it possible to chemically transform almost all types of organic compounds through hydrolysis, ionic, or radical reactions [12]. Reactions proceed in sub- and supercritical water in fundamentally different ways. In general, ionic reactions are peculiar to the hydrothermal liquefaction in the subcritical water conditions, whereas reactions occurring in supercritical water are the free-radical reactions [12]. Despite said general dependency of the reaction type on the water conditions, there are studies reporting that ionic reactions can still happen in supercritical water, as was shown by Ciuffi et al. [22].

The process is typically carried out in an aqueous medium at temperatures ranging from $250^{\circ} \mathrm{C}$ to $380^{\circ} \mathrm{C}$ and pressures ranging from 4 to $25 \mathrm{MPa}$ [23]. The usual dry matter content in the introduced mixture is from $5 \%$ to $20 \%$ [24], so the biomass can be processed without preliminary drying.

Hydrothermal liquefaction, like conventional pyrolysis, yields three main products: bio-oil, solid residue, and gas phase, as well as an aqueous phase containing soluble products. Liquid organic fraction (bio-oil) is obviously the most valuable product among them. In this regard, the majority of current research is devoted to the search for methods to increase the yield of bio-oil, including the use of catalysts [25,26], the selection of solvents for the extraction of bio-oil from an aqueous solution [27], and the joint processing of various types of raw materials [28].

Using the HTL process typically results in higher quality fuel after drying. As a result, the fuel has a lower oxygen content and a higher calorific value (HHV 33-36 MJ $/ \mathrm{kg}$ ) and thus requires much less effort to condition than pyrolysis oil [29]. According to the literature, hydrothermal liquefaction [30-33] can also provide fuel with a lower cost price of $\$ 0.57-1.2$ per $\mathrm{L}$ (for gasification processes this figure is 1.1-1.73 [12] and for pyrolysis is $1.54-1.78$ [12]), while the fuel will be of reasonably good quality. The ability to process wet raw materials with a moisture content of up to $80 \%$ (for example, sewage sludge, manure, algae, etc.) without the need for drying or other pretreatment is one of the benefits of HTL [34]. Thus, the HTL process should be considered the most promising for the direct transformation of wet algal biomass. 
According to the literature data, a mixture of drifting macroalgae is inevitably contaminated with impurities of foreign fractions to one degree or another. The world's total plastic reserves in the oceans amount to five trillion elements weighing more than 0.25 million tons, while in the surface layer of water, the concentration of plastic reaches half a million elements per square kilometer [35]. Plastic marine debris significantly affects the quality and safety of the aquatic environment, posing a threat to aquatic organisms and human health, and becoming a problem on the path to ensuring food safety [32-39].

Polymers account for approximately $60-90 \%$ of the total mass of marine waste, according to an analysis of the component composition of marine debris [38,39]. Typical polymers and polymer-containing composite in marine debris are high- and low-pressure polyethylene, polyethylene terephthalate, Tetra Pak, polypropylene, and nylon [39,40].

There are few studies on the hydrothermal liquefaction of polymers or their mixtures [40-49], and only a few studies are devoted to the joint recovery of biomass of macroalgae and polymers to produce liquid fuel [50,51].

This article provides an overview of studies on producing fuel from macroalgae and an assessment of the possibility of their joint recovery with marine debris. The article begins with a brief description of the experience of hydrothermal liquefaction of macroalgae, followed by a critical review of recent research in the processing of polymers (as the main representatives of marine debris) and their mixtures with various types of biomasses, including macroalgae. This article also touches upon algae composition, bio-oil yield, product quality, and methods of intensifying the process of hydrothermal liquefaction of biomass.

\section{Experience of Hydrothermal Liquefaction of Macroalgae}

\subsection{Using Macroalgae for Biofuel Production in a One-Step Process}

Macroalgae composition analysis. The total lipid content of macroalgae ranges from $1 \%$ to $6 \%$ (dry weight), which is much lower than that of microalgae $(7-23 \% \mathrm{~d} . \mathrm{m}$.), and the ash content of macroalgae ranges from $21 \%$ to $90 \%$ (dry weight) depending on the species [31,52-54].

Analysis of literature data and preliminary field studies carried out in the summer and autumn of 2021 in the Kaliningrad region showed that the dominant species are macroalgae of four genera: Ulva sp., Cladophora sp., Furcellaria sp., and Polisyphonia [55]. Table 1 presents the main parameters of their physical and chemical composition [55-60].

Table 1. The composition of the Baltic Sea macroalgae.

\begin{tabular}{lcccc}
\hline \multirow{2}{*}{ Species } & Derbesia & Ulva & Cladophora & Polysiphonia \\
\cline { 2 - 4 } & \multicolumn{4}{c}{ Value in Mass \% d.m. } \\
\hline Ash & 34.7 & $30.7-31.4$ & $17.8-25.5$ & $15.1-32.32$ \\
Moisture & 6.4 & 7.2 & $5.7-6.7$ & - \\
Lipid & 10.4 & $8.3-12.5$ & $4.6-5.3$ & $0.33-2.78$ \\
Protein & 21.6 & $14.27-16.35$ & $17.8-26.8$ & $11.7-34.45$ \\
Carbohydrates & 26.9 & $28.65-43.6$ & $44.4-45.4$ & - \\
C & 29.2 & 27.7 & $30.9-37.5$ & - \\
H & 4.8 & 5.5 & $5.0-5.9$ & - \\
O & 27.4 & 41.1 & $32.9-34.9$ & - \\
N & 4.5 & 3.5 & $5.2-6.5$ & - \\
S & 2.8 & 5.0 & $1.8-2.3$ & - \\
HHV $(\mathrm{MJ} / \mathrm{kg})$ & 12.4 & 11.7 & $12.7-16.4$ & 15.8 \\
\hline
\end{tabular}

According to some studies, the main disadvantages of marine multicellular algae, from the point of view of obtaining fuel, are low lipid content, large size, and a rigid cell wall which does not allow the use of algae directly as raw material in a one-stage mode; a preliminary processing stage is required $[56,57]$.

A recent study of the composition of 10 macroalgae species found in the Red Sea off the coast of Jeddah showed a slightly different picture. A fairly high lipid content was 
found in the biomass of Ulva lactuca (12.5\%), Padina boryana (10.9\%), and Ulva intestinalis (11.6\%) [58].

Neveux et al. [59] also studied several types of macroalgae for biofuel production and determined that the algae Derbesia tenuissima, Ulva ohnoi, and Oedogonium sp. are promising candidates in terms of high bio-oil yields and quality. The same research group conducted an economic analysis of the process and concluded that protein extraction before HTL will increase the value of the feedstock compared to one-stage hydrothermal liquefaction [60] and will provide additional economic benefits from protein sales.

Careful consideration of the data on the macroalgae composition shows their rather low calorific value in comparison with woody biomass (for example, for conifers HHV is $18.66 \mathrm{MJ} / \mathrm{kg}$ ), which is associated with the high moisture and ash content in algae (for example, the ash content of coniferous firewood species is lower by an order of magnitude and is no more than $3.2 \%$ of dry weight) and a low carbon concentration in the composition of macroalgae (1.7 times lower than in coniferous wood).

Simultaneously, there is a significant content of nitrogenous compounds (primarily proteins), posing an obvious task for scientists to search for alternative methods of transforming macroalgae that ensure maximum utilization of algae resource potential.

Main results of hydrothermal liquefaction of macroalgae. Analysis of the presented means of processing macroalgae show that one-stage hydrolysis without catalytic systems provides a low degree of conversion. Biswas et al. used the macroalgae Sargassum tenerrimum for the production of bio-oil by hydrothermal liquefaction. The process was carried out at $260-300{ }^{\circ} \mathrm{C}$; the reaction time was $15 \mathrm{~min}$. The maximum oil yield (16.3 wt $\left.\%\right)$ was obtained at $280^{\circ} \mathrm{C}$. The analysis showed that the content of organic acids in bio-oils decreased with an increase in temperature from 260 to $300{ }^{\circ} \mathrm{C}$ [61]. Similar results were obtained by Arun et al. [28], Elliott [62], and other authors (see Table 2), but maximum oil yield was a bit higher: for Amphiroa fragilissima oil yield was $28.9 \%$ at $320{ }^{\circ} \mathrm{C}(\mathrm{HHV}$ of the fuel-23.25 MJ $/ \mathrm{kg}$ ) and for Saccharina spp. oil yield was $27.7 \%$ at $364{ }^{\circ} \mathrm{C}$.

Table 2. Results of hydrothermal liquefaction of macroalgae.

\begin{tabular}{|c|c|c|c|}
\hline Algae Type & Conditions & Fuel Yield Efficiency & Reference \\
\hline \multicolumn{4}{|c|}{ HTL water as solvent, without catalyst } \\
\hline Sargassum tenerrimum & Temperature $260-300^{\circ} \mathrm{C}, 15 \mathrm{~min}$ & Maximum $16.3 \%$ & [61] \\
\hline Amphiroa fragilissima & Temperature $280^{\circ} \mathrm{C}$, pressure $16-24 \mathrm{MPa}$ & Maximum fuel yield $28.9 \%$ & [28] \\
\hline Saccharina spp. & $364{ }^{\circ} \mathrm{C}, 40 \mathrm{~min}$ & Maximum fuel yield was $27.7 \%$ & [62] \\
\hline \multicolumn{4}{|c|}{ HTL different solvents, with or without catalyst } \\
\hline Gracilaria corticata & $\begin{array}{l}\text { Temperature } 260,280,300^{\circ} \mathrm{C} \text {, solvent: } \\
\text { water, ethanol, methanol, acetone, a } \\
\text { mixture of ethanol and water }\end{array}$ & $\begin{array}{l}\text { Maximum yield } 16.6 \% \text { (with acetone), } \\
5.25 \mathrm{wt} \% \text { (water) }\end{array}$ & [63] \\
\hline $\begin{array}{l}\text { Enteromorpha clathrata; mixture } \\
\text { with rice husk }\end{array}$ & $\begin{array}{l}\text { Optimal conditions: temperature } 300^{\circ} \mathrm{C} \text {, } \\
50 \% \text { ethanol as a co-solvent, } 45 \mathrm{~min}\end{array}$ & $\begin{array}{l}\text { Maximum oil yield } 71.7 \% \text { for the mixture } 1: 1 \\
\text { algae:husk. For Enteromorpha cl. maximum } \\
\text { yield } 26.0 \%\end{array}$ & [64] \\
\hline Oedogonium intermedium & $\begin{array}{l}\text { Temperature } 350{ }^{\circ} \mathrm{C}, 3 \mathrm{~min} \text {, solvents: } 10 \% \\
\text { N-heptane and } 10 \% \text { toluene, } 10 \% \text { anisole }\end{array}$ & $\begin{array}{l}\text { Maximum fuel yield was } 24.0 \% \text { with water, } \\
20 \% \text { with N-heptane, } 21 \% \text { with toluene and } \\
28 \% \text { with anisole }\end{array}$ & [65] \\
\hline Enteromorpha clathrata & $\begin{array}{l}\text { Temperature } 250-350{ }^{\circ} \mathrm{C} \text {, pressure } \\
5-45 \mathrm{MPa} \text {, co-solvent ethanol 0-100\%, } \\
15-75 \mathrm{~min} \text {, catalysts HZSM-5 }(10-30 \%)\end{array}$ & $\begin{array}{l}\text { Maximum oil yield } 46.75 \% \text { with a } \\
\text { conversion rate of } 95.5 \% \text { with } 300{ }^{\circ} \mathrm{C} \text {, } \\
45 \text { min, } 75 \% \text { ethanol; with HZSM- } 5 \text { oil yield } \\
\text { decreased to } 44.5 \%\end{array}$ & [66] \\
\hline Gracilaria corticata & $\begin{array}{l}\text { Temperature } 260-300{ }^{\circ} \mathrm{C} \text { with iron-nickel } \\
\text { catalysts at a temperature of } 260-300{ }^{\circ} \mathrm{C} \\
\text { using water, methyl, and ethyl alcohol } \\
\text { as solvents }\end{array}$ & $\begin{array}{l}\text { Maximum fuel yield was } 56.2 \% \text { when using } \\
\text { Ga/NiFe-LDO/AC catalyst at } 280^{\circ} \mathrm{C}\end{array}$ & [67] \\
\hline
\end{tabular}


Table 2. Cont.

\begin{tabular}{|c|c|c|c|}
\hline Algae Type & Conditions & Fuel Yield Efficiency & Reference \\
\hline Sargassum tenerrimum & $\begin{array}{l}\text { Temperature } 260,280 \text {, and } 300{ }^{\circ} \mathrm{C} \text {, } \\
\text { pressure } 4.5-12 \mathrm{MPa} \text {, catalysts: } \mathrm{CaO} \text {, } \\
\text { applied on } \mathrm{CeO}_{2}, \mathrm{Al}_{2} \mathrm{O}_{3} \text { and } \mathrm{ZrO}_{2} \text { in } \\
\text { doses of } 5 \text { to } 25 \mathrm{wt} \% \text {. Contact time } 15 \mathrm{~min} \text {. } \\
\text { Solvent: water, ethanol, and a mixture of } \\
\text { water: ethanol }\end{array}$ & $\begin{array}{l}\text { The fuel yield in the non-catalytic process } \\
\text { was } 3.3 \mathrm{wt} \%, 23.3 \mathrm{w} \mathrm{t} \% \text {, and } 32.0 \mathrm{wt} \% \text { when } \\
\text { using water, ethanol, and their mixture, } \\
\text { respectively. In the catalytic process, the } \\
\text { maximum yield when using } \mathrm{CaO} / \mathrm{ZrO}_{2} \text { as a } \\
\text { catalyst was } 25.2 \mathrm{wt} \% \text { and } 33.0 \mathrm{wt} \% \text { when } \\
\text { using ethanol and a mixture of ethanol and } \\
\text { water, respectively }\end{array}$ & {$[68]$} \\
\hline \multicolumn{4}{|c|}{ Homogeneous acid/alkaline catalysts with water as solvent } \\
\hline Spirulina platensis & $300{ }^{\circ} \mathrm{C}, 35 \mathrm{~min}, 0.34 \%$ catalysts $\mathrm{CH}_{3} \mathrm{COOH}$ & $\begin{array}{l}\text { Maximum fuel yield } 29.7 \% \text { without catalyst, } \\
\text { with } \mathrm{CH}_{3} \mathrm{COOH} 28 \%\end{array}$ & {$[69]$} \\
\hline Ulva prolifera & $\begin{array}{l}\left.\text { Temperature } 270,290 \text {, and } 310^{\circ} \mathrm{C}\right) \text { and } \\
\text { reaction time }(10,20 \text {, and } 30 \mathrm{~min}) \text {, } \\
\text { catalysts: } \mathrm{KOH}, \mathrm{NaOH} \text { and } \mathrm{Na}_{2} \mathrm{CO}_{3}\end{array}$ & $\begin{array}{l}\text { Maximum yield was } 12.0 \mathrm{wt} \% \text { at } 290^{\circ} \mathrm{C} \\
\text { without catalysis. In the catalytic reaction, } \\
\text { the maximum yield was } 26.7 \mathrm{wt} \% \text { when } \\
\text { using } \mathrm{KOH}\end{array}$ & {$[70]$} \\
\hline Sargassum patens & $\begin{array}{l}\text { Temperature } 340{ }^{\circ} \mathrm{C} \text {, time } 15 \mathrm{~min} \text {, catalyst: } \\
5 \% \mathrm{Na}_{2} \mathrm{CO}_{3}\end{array}$ & $\begin{array}{l}\text { Maximum yield was without catalyst } 32 \% \text {, } \\
\text { with } \mathrm{Na}_{2} \mathrm{CO}_{3} \text { yield was } 28 \%\end{array}$ & {$[71]$} \\
\hline Cladophora sociali & $\begin{array}{l}\text { Temperature } 350{ }^{\circ} \mathrm{C} \text {, catalysts: } \mathrm{KOH}, \\
\mathrm{K}_{2} \mathrm{CO}_{3}, \mathrm{H}_{3} \mathrm{PO}_{4}, \mathrm{HCOOH} \text {, zeolites, Ni-Re, } \\
\mathrm{Ru} / \mathrm{C}, \mathrm{Fe}\end{array}$ & $\begin{array}{l}\text { Maximum yield was } 36.2 \% \text { in the presence } \\
\text { of Fe }\end{array}$ & {$[72]$} \\
\hline \multicolumn{4}{|c|}{ Heterogeneous catalysts with water as solvent } \\
\hline Ulva prolifera & $\begin{array}{l}\text { Temperature } 260-300{ }^{\circ} \mathrm{C} \text {, time } 15-45 \mathrm{~min} \text {, } \\
\text { pressure } 4.3-7 \mathrm{MPa} \text {, catalyst: zeolites }\end{array}$ & $\begin{array}{l}\text { The maximum bio-oil yield was } 16.6 \mathrm{wt} \% \\
\text { without catalyst and } 29.3 \mathrm{wt} \% \text { with catalyst }\end{array}$ & {$[73]$} \\
\hline Spirulina platensis & $\begin{array}{l}\text { Temperature } 320^{\circ} \mathrm{C}, 37 \mathrm{~min} \text {, catalysts } \\
0.15 \% \mathrm{Fe}_{3} \mathrm{O}_{4}\end{array}$ & $\begin{array}{l}\mathrm{HHV} \text { rose from } 23.5 \% \text { to } 30.98 \mathrm{MJ} / \mathrm{kg} \text { and } \\
\text { fuel yield rose from } 24.5 \% \text { to } 32.3 \% \\
\text { with } \mathrm{Fe}_{3} \mathrm{O}_{4}\end{array}$ & {$[74]$} \\
\hline Spirulina platensis & $\begin{array}{l}\text { Temperature } 250{ }^{\circ} \mathrm{C}, 30 \mathrm{~min} \text {, catalysts } \\
0.4 \% \mathrm{CeO}_{2}\end{array}$ & $\begin{array}{l}\text { Fuel yield without catalyst } 16 \% \text {, } \\
\text { with } \mathrm{CeO}_{2}-26 \%(+62.5 \%)\end{array}$ & {$[75]$} \\
\hline
\end{tabular}

The experience of using co-solvents that provide on average a three-fold increase in biofuel yield is of interest. Fernandes et al. processed red algae Gracilaria corticata at $260{ }^{\circ} \mathrm{C}, 280{ }^{\circ} \mathrm{C}$, and $300{ }^{\circ} \mathrm{C}$ using water, ethanol, methanol, acetone, and a mixture of ethanol and water as solvents and obtained maximum yield (16.16 wt\%) of bio-oil in the experiment with acetone at $300{ }^{\circ} \mathrm{C}$; when using water at the same temperatures, the yield was $5.25 \mathrm{wt} \%$ [63].

Assessing influence of alcohol co-solvent and catalysis with HZSM-5 on HTL of Enteromorpha clathrata, Yuan et al. [64] showed that presence of HZSM-5 slightly reduced the oil yield, however it enhanced the quality of oil by forming ester compounds.

This effect of ethanol is associated with its lower dielectric constant and, as a consequence, a higher ability to degrade macromolecules. In addition, the likelihood of its repolymerization increases.

The addition of ethanol significantly affected the fuel yield, providing an increase in yield from $17 \%$ to $46.75 \%$ (+175\%) with the addition of ethanol $75 \%$ by weight. However, the authors recommend using an ethanol concentration of $50 \%$, since this gives an almost identical effect to increase the fuel yield, while the load on the reactor is significantly reduced (the pressure is $70 \%$ lower) and the operating costs are reduced.

The average increase in the yield of biofuel when using alcohols as co-solvents is $175-700 \%$, while the effective dose of alcohol is $50-75 \%$ [63-65].

Poor results were achieved by the group of scientists using 10\% N-heptane, $10 \%$ toluene, and $10 \%$ anisole as co-solvents; fuel yield decreased in comparison with water use from $24.0 \%$ to $20-21 \%$.

One of the promising options for hydrothermal liquefaction process modernization is the use of catalysis. The use of catalytic systems reduces the pressure of the process and temperature (which in turn causes a decrease in capital and operating costs), increases the yield of biofuel, and improves its quality. The existing catalysts can be divided into two 
groups: heterogeneous and homogeneous catalysts. Alkaline catalysts and acids are more commonly used as homogeneous catalysts.

Vietnamese researchers processed Cladophora sociali macroalgae in the presence of homogeneous $\left(\mathrm{KOH}, \mathrm{K}_{2} \mathrm{CO}_{3}, \mathrm{H}_{3} \mathrm{PO}_{4}, \mathrm{HCOOH}\right)$ and heterogeneous (zeolite, Ni-Re, $\mathrm{Ru} / \mathrm{C}, \mathrm{Fe}$ ) catalysts at $350{ }^{\circ} \mathrm{C}$. The maximum yield (36.2\%) and the minimum content of heteroatoms were achieved using metallic iron as a catalyst [72].

As previously stated, the use of catalytic systems in the hydrothermal process allows for increased fuel yield and quality. Macroalgae Ulva prolifera were treated at different temperatures $\left(270{ }^{\circ} \mathrm{C}, 290^{\circ} \mathrm{C}\right.$, and $310^{\circ} \mathrm{C}$ ) and reaction times (10, 20, and $\left.30 \mathrm{~min}\right)$. The process was carried out in the presence of basic homogeneous catalysts $(\mathrm{KOH}, \mathrm{NaOH}$, and $\mathrm{Na}_{2} \mathrm{CO}_{3}$ ). The maximum bio-oil yield during non-catalytic liquefaction was $12.0 \mathrm{wt} \%$ at $290{ }^{\circ} \mathrm{C}$. In the catalytic reaction, the maximum bio-oil yield ( $\left.26.7 \mathrm{wt} \%\right)$ was observed when $\mathrm{KOH}$ was used as a catalyst. The catalytic process allowed for an increasing in the calorific value of the fuel (HHV) by 58.5\% [70].

The peculiarity of using homogeneous catalysis is that their regeneration is practically impossible. Effectiveness of alkaline catalysis is quite moderate [70] or even negative [71]. The use of alkalis only provides a decrease in the likelihood of repolymerization of products, which ensures a decrease in the yield of biochar and an increase of liquid fuel yield. Acid catalysis, as a rule, leads to negative consequences, increasing the rate of repolymerization of molecules in solution, reducing the yield of biofuel, and increasing the yield of the solid fraction $[31,69,72]$.

The significant advantage of using mineral and metal-containing heterogeneous catalysts is the possibility of their regeneration and multiple use. The mechanism of metalcontaining catalysts is in adsorption on the surface of organic molecules, which leads to a decrease in the activation energy, and, as a consequence, causes increase in the yield of products and a decrease in the required temperature and pressure. The data in Table 2 indicate the unequivocal effectiveness of this type of catalysis in relation to any type of algae.

Hydrothermal processing of the macroalgae Gracilaria corticata was carried out using a series of iron-nickel catalysts at $260-300{ }^{\circ} \mathrm{C}$ using water, methyl, and ethyl alcohol as solvents which allowed for establishing that the maximum fuel yield (56.2 $\mathrm{wt} \%$ ) is achieved when using a $\mathrm{Ga} / \mathrm{NiFe}-\mathrm{LDO} / \mathrm{AC}$ catalyst at $280^{\circ} \mathrm{C}$ [67].

Biswas et al. [68] studied the Sargassum tenerrimum macroalgae as an object of hydrothermal processing. The process was carried out at different temperatures (260, 280, and $300{ }^{\circ} \mathrm{C}$ ), the pressure varied from 4.5 to $12 \mathrm{MPa}$ in the presence of heterogeneous basic catalysts $\left(\mathrm{CaO}\right.$, applied to $\mathrm{CeO}_{2}, \mathrm{Al}_{2} \mathrm{O}_{3}$, and $\left.\mathrm{ZrO}_{2}\right)$ and without a catalyst. The catalyst dose varied from 5 to $25 \mathrm{wt} \%$. The contact time was $15 \mathrm{~min}$. Water, ethanol, and a mixture of water and ethanol were used as solvents. The fuel yield in the non-catalytic process was $3.3 \mathrm{wt} \%, 23.3 \mathrm{wt} \%$, and $32.0 \mathrm{wt} \%$ when using water, ethanol, and their mixture, respectively.

In the catalytic process, the best results were obtained using $\mathrm{CaO} / \mathrm{ZrO}_{2}$ as a catalyst $(10.0 \mathrm{wt} \%)$, which provided a fuel yield of $25.2 \mathrm{wt} \%$ and $33.0 \mathrm{wt} \%$ when using ethanol and a mixture of ethanol and water, respectively. The fuel obtained as a result of the catalytic process had a HHV of $27.9 \mathrm{MJ} / \mathrm{kg}$ (in a non-catalytic process with water as a solvent, the $\mathrm{HHV}$ was $20 \%$ lower and amounted to $22.4 \mathrm{MJ} / \mathrm{kg}$ ) [68].

The use of zeolites as a catalyst (dose from 10-20\% by weight) allowed the group of authors [73] to increase the fuel yield during the processing of Ulva prolifera from $16.6 \mathrm{wt} \%$ to $29.3 \mathrm{wt} \%$ and to increase the HHV of the fuel from $21.2 \mathrm{MJ} / \mathrm{kg}$ to $32.2-34.8 \mathrm{MJ} / \mathrm{kg}$ under other identical conditions. The process was carried out at $260-300{ }^{\circ} \mathrm{C}$ for $15-45 \mathrm{~min}$ and a 4.3-7.0 MPa pressure.

The innovations in the HTL process described above include the use of heterogeneous and homogeneous catalysis, as well as the use of co-solvents (alcohols, ketones). Both of these areas face a range of technological challenges. Heterogeneous catalysis is associated with the problem of catalyst deactivation. The use of homogeneous catalysts and/or cosolvents leads to their irreversible loss in the technological process and, as a consequence, high capital costs. 
Recently, one of the most important trends in biomass processing has been the concept of cascade conversion, which allows for the consistent production of the greatest number of valuable products. Macroalgae can potentially be used in various sectors of biotechnology, such as the production of biofuels, food, and cosmetic and medical products $[17,76]$.

This strategy for algae consists of the initial production of bioactive compounds (lipids, vitamins) and the subsequent conversion of biomass (hydrolysis, pyrolysis, fermentation, and liquefaction) to produce fuel with the subsequent disposal of fermented or recycled waste in the form of compost, sorbents, etc. [17]. One of the options for organizing a cascade technology for processing macroalgae is considered in the next section.

\subsection{Application of a Two-Stage Hydrothermal Liquefaction Process for Algae Conversion}

One of the disadvantages of HTL is that the proteins and carbohydrates contained in algae greatly affect the quality of the final product, leading to high oxygen and nitrogen content, which in turn increases the acidity of the fuel, the tendency to polymerize, and the viscosity, and reduces the proportion of light fractions [77].

These undesirable reactions ultimately represent the loss of nutrients from biomass processing systems and further limit the potential applications of biofuels [17]. Proteins from algae have a balanced composition, not inferior in properties to proteins from traditional sources [78]. Therefore, preliminary removal and recovery of protein compounds and carbohydrates from biomass is useful and necessary in the implementation of HTL processes.

There are a number of different methods for reducing the content of nitrogenous compounds in algal biomass, including enzymatic, acidic, or alkaline hydrolysis, but these methods are associated with the expensive subsequent separation of proteins and their derivatives [78].

Several authors [78-80] proposed the use of low-temperature pretreatment in an aqueous medium, leading to the transition of a part of nitrogen-containing compounds into the aqueous phase without significant lipid destruction.

One of the options for implementing this approach is a two-stage HTL process. The two-stage HTL process was developed for the simultaneous extraction of proteins and carbohydrates from algal biomass in the first stage at low temperatures $\left(140-180^{\circ} \mathrm{C}\right)$ and the production of biofuels through the conversion of lipids in the second stage $\left(220-280{ }^{\circ} \mathrm{C}\right)$ [51]. The general technological scheme of the two-stage process is shown in Figure 1.

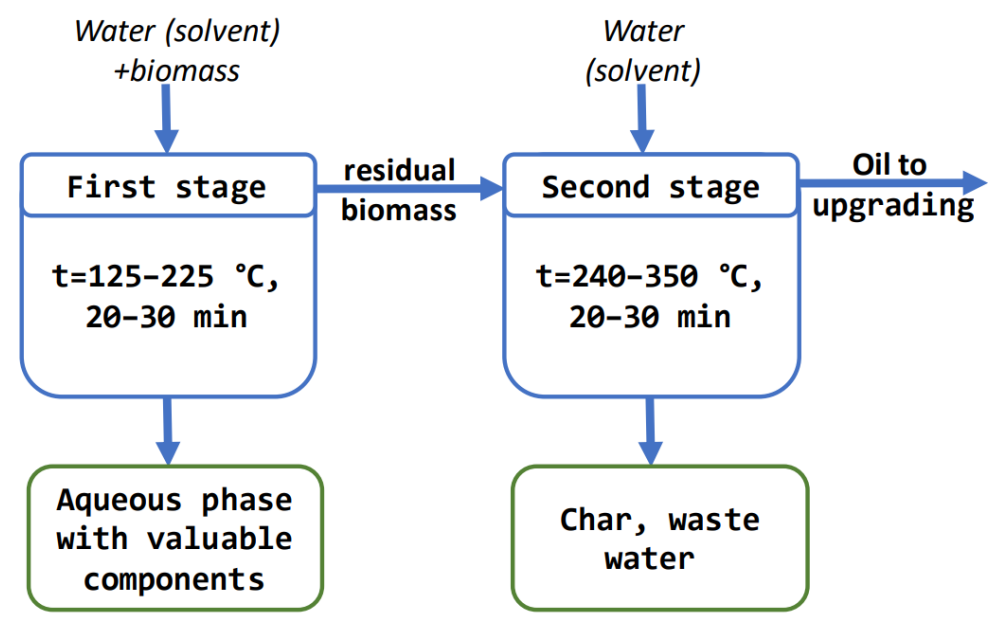

Figure 1. Scheme of carrying out a two-stage HTL process.

Fine tuning of the first stage reaction conditions can enhance favorable reaction pathways for the selective recovery of compounds such as polysaccharides, proteins, amino acids, pigments, and inorganic nutrients. Moreover, after preliminary removal, the mass transfer between water and lipid molecules is improved, which ultimately improves the efficiency of fuel recovery. 
The cascade extraction of valuable components fully implements the Zero Waste approach, which is a fundamental requirement to implement the bioeconomy amongst EU countries [81]. The key requirement for biomass processing is the primary extraction of the most valuable bioactive substances and nutrients, followed by biofuel production from the residues [82].

The process of cascade hydrothermal extraction of valuable components is subsequently carried out in two reactors. Water is used as a solvent. At the first stage, the process is carried out at $150-160{ }^{\circ} \mathrm{C}$ with a processing time of $20-30 \mathrm{~min}$. After the first stage reaction, the reaction mixture is filtered and the treated algae in solid form is loaded into the second reactor with an additional dose of water at the desired ratio. In the second stage, the treated biomass is processed at temperatures ranging from 240 to $250{ }^{\circ} \mathrm{C}$ and $3.5 \mathrm{MPa}$, which is much lower than in the one-stage HTL process.

Most studies on the implementation of the two-stage process are devoted to the processing of microalgae. Miao et al. [83] concluded that the extraction of higher polysaccharides is achieved at the first stage at $160{ }^{\circ} \mathrm{C}$ in $20 \mathrm{~min}$ with a biomass ratio of 1:9. In the second stage, $240{ }^{\circ} \mathrm{C}, 20$ mins, and a loading ratio of $1: 9$ are sufficient.

Chakraborty et al. [84] studied three different scenarios of hydrothermal liquefaction using the example of Chlorella sorokiniana: one stage, two stage, and three stage. Although the one-stage process produced the highest bio-oil yield $(28 \%)$, the two-stage process produced a high yield of polysaccharides (26\%) as well as a relatively high amount of biooil $(23 \%)$, while the bio-char yield was $64 \%$ lower than in the one-stage process. Moreover, two-stage HTL was better than three-stage HTL in terms of bio-oil yield, while the latter was preferred when high polysaccharide yields were required. Miao et al. [83] were able to achieve the same biofuel yield as in a one-step process under milder conditions while obtaining polysaccharides/hydrolyzed sugars and proteins/amino acids as by-products from Chlorella sorokiniana.

Prapaiwatcharapan et al. [85] confirmed the higher overall yield and lower nitrogen content of biofuels from the processing of Coelastrum sp. in a two-stage process in a semi-continuous reactor. Jazrawi et al. [80] investigated the processing of the high-protein microalgae Chlorella vulgaris, the two-stage processing of which reduced the nitrogen content in the fuel by 55\%. Selvaratnam et al. [86] investigated the possibility of using the extract obtained at the first stage for the cultivation of an acidophilic strain of Galdieria sulphuraria microalgae. The algae productivity was 2.6 times higher in comparison with the productivity in a pure nutrient medium.

Costanzo et al. [78] carried out a two-stage conversion of the microalgae biomass under the following conditions:

- first stage: $125-225^{\circ} \mathrm{C}, 0.5-30 \mathrm{~min}$

- $\quad$ second stage: $350{ }^{\circ} \mathrm{C}, 60 \mathrm{~min}$

At the same time, primary treatment at higher temperatures and a longer holding time $\left(225^{\circ} \mathrm{C}, 15 \mathrm{~min}\right.$ ) allowed for the extraction of up to $45 \%$ of all nitrogen, which ensured a decrease of its content in the fuel by $26-28 \%$ compared to the one-stage process [78].

Based on the above, we can conclude that the use of a two-stage process clearly has the following advantages over a single-stage process:

- decrease in the amount of nitrogen and oxygen amount in oil phase;

- $\quad$ possibility of valuable component preliminary extraction;

- increase of biomass utilization rate.

It is natural that the preliminary extraction of organic matter leads to the decrease in the yield of liquid fuel. However, the amount of solid residue is significantly reduced and, as a consequence, the effectiveness of algal biomass use is significantly higher.

Extraction of valuable components at the first stage of the HTL process is possible and expedient in the case of using pure, possibly monocultural biomass. Processing washed ashore macroalgae, which are partially decomposed during long drifts in sea water and 
piled up on the shore, may be problematic due to difficulties with the extraction and purification of target components.

The comparison of the fuel yield in a two-stage and one-stage process was carried out by Wang and Zhao [87] using the microalga Enteromorpha clathrata as an example. The process of HTL was carried out in three versions: a one-stage process at 200 and $300{ }^{\circ} \mathrm{C}$ (time $1 \mathrm{~h}$ ) and a two-stage process, $0.5 \mathrm{~h}$ at $200{ }^{\circ} \mathrm{C}$ and then $0.5 \mathrm{~h}$ at $300^{\circ} \mathrm{C}$. In this work, the effect of the ratio biomass to solvent on the yield of liquid fuel was also evaluated, as well as the effectiveness of ethanol as a co-solvent. In the range of the solvent/biomass ratio $40 / 2.4-40 / 5.6$, no significant change in the fuel yield was found. However, an increase in the share of ethanol resulted in a significant increase in oil yield from $8.12 \%$ (minimum oil yield in the absence of alcohol) to $38.4 \%$. The maximum yield of liquid fuel was obtained in a one-stage process $(40.3 \%)$, but it should be noted that in a one-stage process the proportion of the solid phase was higher than in a two-stage process. This is due to the formation at low temperatures of water-soluble products (alcohols, acids, ketones), which subsequently do not transform into biofuel and remain instead in the aqueous phase.

The use of a two-stage process also led to a decrease in the number of nitrogencontaining compounds in the fuel from $37 \%$ to $21.6 \%$ when using water as a solvent and from $28.6 \%$ to $16.8 \%$ in the case of alcohol.

Thus, we can say that the organization of the HTL process in two stages makes sense in the following cases:

- if the goal is to extract valuable components from the aqueous phase after the first stage;

- in the case of using pure, monoculture biomass;

- if it is vitally important to reduce the amount of nitrogen in bio-oil.

In the case of processing macroalgae, which are washed up on the shore and represent a mixture of various brown, red, and green macro- and microalgae, as well as various impurities (polymers, wood, textiles, metals, glass, mineral components, etc.), the organization of a two-stage process is meaningless since in general this approach reduces the yield of liquid fuels.

\section{Prospects for Joint Processing of Macroalgae Biomass and Marine Debris}

There are few studies on the HTL of polymers or their mixtures [40-49] and only two studies are devoted to the joint recovery of macroalgae and polymers with the production of liquid fuel [50,51]. In this connection, it was decided to consider the results of studies pertaining to the HTL of polymers with/or without adding other types of biomasses and to assess the perspectives of their joint processing with algae. Table 3 presents an overview of current research in the field of HTL of polymers and their mixtures with biomass.

Table 3. Overview of polymer processing experiments.

\begin{tabular}{|c|c|c|c|c|}
\hline Polymers & Conditions & Fuel Yield Efficiency & HHV of the Oil & References \\
\hline $\begin{array}{l}\text { High- and low-pressure } \\
\text { polyethylene }\end{array}$ & $\begin{array}{l}\text { Temperature } 400-450{ }^{\circ} \mathrm{C}, 0.5 \text { and } \\
4 \mathrm{~h} \text {. Raw material dose } 1: 1.75\end{array}$ & $\begin{array}{l}\text { The maximum yield ( } 97 \mathrm{wt} \% \text { ) of } \\
\text { a mixture of paraffinic and } \\
\alpha \text {-olefin waxes was obtained at } \\
425^{\circ} \mathrm{C} \text { and } 30-40 \mathrm{~min} \text {. The } \\
\text { maximum fuel yield }(87 \mathrm{wt} \%) \\
\text { was obtained at } 425^{\circ} \mathrm{C}, 2.5 \mathrm{~h} \text { or } \\
450^{\circ} \mathrm{C}, 45 \mathrm{~min} \text {. }\end{array}$ & $42.7-42.9 \mathrm{MJ} / \mathrm{kg}$ & {$[43]$} \\
\hline $\begin{array}{l}\text { Polypropylene and } \\
\text { polyethylene }\end{array}$ & $\begin{array}{l}\text { Pressure } 0.25,1.55,3.75,10.25 \text {, } \\
\text { and } 23 \mathrm{MPa} \text {. Polymer: water } \\
\text { ratio } 1: 1.75 ; 200: 1 ; 7.3: 1 ; 2.3: 1 \text {, } \\
\text { time } 45-60 \mathrm{~min}, \\
\text { temperature } 450{ }^{\circ} \mathrm{C}\end{array}$ & $\begin{array}{l}\text { The minimum coal yield and the } \\
\text { optimum degree of destruction } \\
\text { were achieved at a water content } \\
\text { of } 5 \% \text { and } 1.55 \mathrm{MPa} \text {. The light } \\
\text { ends of the fuel, obtained from a } \\
\text { mixture of PP:PE in a 1:1 ratio, } \\
\text { meet all the requirements for } \\
\text { high-quality pure gasoline, and } \\
\text { the heavy ends meet the } \\
\text { requirements for ultra-low sulfur } \\
\text { diesel fuel. }\end{array}$ & $\begin{array}{l}\text { 42.6-42.7 MJ } / \mathrm{kg} \text { for oil } \\
\text { from polyethylene and } \\
42.2-42.4 \mathrm{MJ} / \mathrm{kg} \text { for oil } \\
\text { from polypropylene }\end{array}$ & [44] \\
\hline
\end{tabular}


Table 3. Cont.

\begin{tabular}{|c|c|c|c|c|}
\hline Polymers & Conditions & Fuel Yield Efficiency & HHV of the Oil & References \\
\hline Tetra Pak & $\begin{array}{l}\text { Temperature } 300-420{ }^{\circ} \mathrm{C} \text {, } \\
\text { pressure } 16-24 \mathrm{MPa} \text {, time } \\
5-60 \mathrm{~min} \text {, and polymer } \\
\text { concentration } 5-40 \% .\end{array}$ & $\begin{array}{l}\text { The maximum fuel yield of } \\
35.55 \% \text { was achieved at } 360{ }^{\circ} \mathrm{C} \text {, } \\
22 \mathrm{MPa}, 30 \mathrm{~min} \text { and a feed } \\
\text { concentration of } 20 \mathrm{wt} \% \text {. The } \\
\text { maximum fuel calorific value of } \\
48.747 \mathrm{MJ} / \mathrm{kg} \text { and the maximum } \\
\text { energy extraction efficiency of } \\
46.49 \% \text { were observed at } 420{ }^{\circ} \mathrm{C} \text {, } \\
20 \mathrm{MPa}, 30 \mathrm{~min} \text { and a feed } \\
\text { concentration of } 20 \mathrm{wt} \%\end{array}$ & $\begin{array}{l}\text { The maximum fuel HHV } \\
48.747 \mathrm{MJ} / \mathrm{kg} \text { and the } \\
\text { maximum energy } \\
\text { extraction efficiency of } \\
46.49 \% \text { were observed at } \\
420{ }^{\circ} \mathrm{C}, 20 \mathrm{MPa}, 30 \mathrm{~min} \\
\text { and a feed concentration } \\
\text { of } 20 \mathrm{wt} \% \text {. }\end{array}$ & [45] \\
\hline
\end{tabular}

12 polymers: polyacrylonitrylbutadiene-styrene (ABS), bisphenol-A epoxy resin, high pressure polyethylene, low pressure polyethylene, polyamide 6 polyamide 66 , polyethylene terephthalate, polycarbonate, polypropylene, polystyrene and polyurethane foam polyvinyl chloride.

Polybutylene terephthalate, polycarbonate, polyethylene terephthalate, polylactate, polymethyl methacrylate, polyoxymethylene, styrene butadiene (SBD), polyvinyl acetate (PVA)

Polypropylene, polystyrene, polycarbonate, and polyethylene terephthalate.

Time: $0.5 \mathrm{~h}, 1 \mathrm{~h}$, temperature $350-450{ }^{\circ} \mathrm{C}$, pressure 16.52 and $25 \mathrm{MPa}$

Temperature $350{ }^{\circ} \mathrm{C}$, exposure time $14 \mathrm{~min}$ and 1:17 (polymer:water ratio), catalyst $\mathrm{KOH} 17.2 \mathrm{~g} / \mathrm{L}$

Temperature $400{ }^{\circ} \mathrm{C}, 25 \mathrm{MPa}$,

15 min, raw material dose 1:10

Polymer mixture: cellulose, PET, nylon, PVA, polyethylene, polypropylene

Temperature $340{ }^{\circ} \mathrm{C}, 5 \mathrm{~h}$, raw material dose $1: 10$, catalyst $2 \%$ $\mathrm{NaOH}$ (for PET hydrolysis)
LDPE, HDPE, PP, and PS

showed a solid yield of more

than $90 \%$, the formation of oil

did not exceed $5 \%$. The catalyst

allowed increasing the

destruction of ABS, epoxy resin,

polyamides, $\mathrm{PET}$, polycarbonate,

and polyurethane foam to

achieve an average solid fraction

yield of $0-25 \%$, while without a

catalyst this value was $50-86 \%$.

The synthetic crude oil yield

ranged from $0 \%$ (for PET, PBT,

polylactate) and almost $100 \%$ for

PC. SBD and PVA also

demonstrated high biofuel yield

up to $80 \%$

The maximum yield was from 16 $\mathrm{wt} \%$ for PET and up to $86 \mathrm{wt} \%$ for polystyrene.

Depolymerization of plastics to

oil was fastest under

supercritical conditions

$\left(\mathrm{T}>400{ }^{\circ} \mathrm{C}\right)$.

Comparison of the results of the

two tests showed that the

addition of $\mathrm{NaOH}$ led to a

decrease in the percentage of

solid residue (from $75.1 \%$ to

$65.5 \%$ ) and an increase in the

percentage of water-soluble organic substances (from $6.2 \%$ to

$16 \%)$, the fuel yield remained

practically the same $(7.7 \%$ and

$7.4 \%$, respectively). $\mathrm{n} / \mathrm{a}$

[42]

$\mathrm{n} / \mathrm{a}$

30-46 MJ/kg for oil from

polypropylene;

36-46 MJ $/ \mathrm{kg}$ for oil from

polystyrene; $28-30 \mathrm{MJ} / \mathrm{kg}$

for oil from polycarbonate;

28-29 MJ/kg for oil from PET
Polyolefins led to a decrease in bio-oil yield from $34 \%$ to $20 \%$, PET and nylon provided a slight increase in oil yield to 36.1 and $34.6 \%$, respectively.
$34 \mathrm{MJ} / \mathrm{kg}$ for oil from pistachio shells; shells with $10-20 \%$ of PET 33-35 MJ/kg; shells with $10-20 \%$ of $\mathrm{PE}$

$37-38 \mathrm{MJ} / \mathrm{kg}$; shells with Temperature $350^{\circ} \mathrm{C}$, time 15 , and $60 \mathrm{~min}$. polypropylene, nylon-6 shrub and polyolefins
Biomass: Polymers Ratio: 0:1,

1:0, 1:1, 2:1, 3:1, 4:1, and 5:1, temperature $340-440{ }^{\circ} \mathrm{C}$, catalyst: bentonite clay activated with hydrochloric acid
The maximum bio-oil yield was about $61.23 \mathrm{wt} \%$ at $420^{\circ} \mathrm{C}$ for a

3:1 mixture with the addition of $3 \mathrm{wt} \%$ catalyst with a holding time of $60 \mathrm{~min}$.
32-33 MJ/kg; shells with

$10-20 \%$ of nylon

$32.5-33 \mathrm{MJ} / \mathrm{kg}$.

$45.2 \mathrm{MJ} / \mathrm{kg}$ for oil from

Prosopis juliflora:

$44.18 \mathrm{MJ} / \mathrm{kg}$ for oil from

polyolefins; $46.0 \mathrm{MJ} / \mathrm{kg}$

for oil from blend 3:1 
Table 3. Cont.

\begin{tabular}{|c|c|c|c|c|}
\hline Polymers & Conditions & Fuel Yield Efficiency & HHV of the Oil & References \\
\hline $\begin{array}{l}\text { Cellulose, starch, soy protein } \\
\text { isolate, lignin, stearic acid, } \\
\text { glucose and various } \\
\text { polymers: polypropylene, } \\
\text { polystyrene, polycarbonate, } \\
\text { and polyethylene } \\
\text { terephthalate }\end{array}$ & $\begin{array}{l}\text { Time: } 0.5 \mathrm{~h} \text {, temperature } 300,350 \text {, } \\
400,425^{\circ} \mathrm{C} \text {, pressure } 25 \mathrm{MPa}\end{array}$ & $\begin{array}{l}\text { Increase in oil yield by two } \\
(45 \%) \text {, with joint processing with } \\
\text { polystyrene, decrease in the } \\
\text { decomposition temperature of } \\
\text { polyolefins (up to } 300^{\circ} \mathrm{C} \text { ). }\end{array}$ & $\begin{array}{l}\text { 27.9-32.1 MJ/kg for oil } \\
\text { from biomolecules blend; } \\
36.4-38.5 \mathrm{MJ} / \mathrm{kg} \text { for oil } \\
\text { from polymers blend; } \\
30.9-34.0 \mathrm{MJ} / \mathrm{kg} \text { for oil } \\
\text { from } 9 \text { components blend } \\
\text { (polymers and } \\
\text { biomolecules) }\end{array}$ & [90] \\
\hline $\begin{array}{l}\text { A mixture of macroalgae } \\
\text { and plastic marine debris } \\
\text { (polyethylene, } \\
\text { polypropylene, nylon) }\end{array}$ & $\begin{array}{l}\text { Temperature } 340{ }^{\circ} \mathrm{C} \text {, pressure } \\
16.5 \mathrm{MPa} \text {, time } 12 \text { and } 27 \mathrm{~min} \text {, } \\
\text { plastic dose } 0,10 \%, 25 \%, 50 \% \text { of } \\
\text { the mixture mass }\end{array}$ & $\begin{array}{l}\text { The biofuel yield did not exceed } \\
15 \% \text {, but with the addition of } \\
\text { plastics, a significant increase } \\
\text { was noted (from } 10 \% \text { to } 15 \% \text { ), } \\
\text { the calorific value of the fuel } \\
\text { increased from } 33.5 \text { to } \\
39.0 \mathrm{MJ} / \mathrm{kg}\end{array}$ & $\begin{array}{l}\text { With the addition of } \\
\text { plastics, a significant } \\
\text { increase was noted (from } \\
10 \% \text { to } 15 \% \text { ), HHV of the } \\
\text { fuel increased from } 33.5 \text { to } \\
39.0 \mathrm{MJ} / \mathrm{kg}\end{array}$ & [91] \\
\hline $\begin{array}{l}\text { A mixture of Fucus serratus } \\
\text { macroalgae and nylon }\end{array}$ & $\begin{array}{l}350{ }^{\circ} \mathrm{C} \text { during } 10 \mathrm{~min}, 4 \text { grades } \\
\text { of nylon: nylon } 6 \text {, nylon } 6 / 6 \text {, } \\
\text { nylon } 12 \text {, and nylon } 6 / 12 \text { in a } \\
\text { mixture of } 5,20 \text {, and } 50 \mathrm{wt} \% \\
\text { nylon in relation to biomass }\end{array}$ & $\begin{array}{l}100 \% \text { of nylon } 6 \text { and } 6 / 6 \\
\text { degrades under HTL conditions } \\
\text { while forming cyclopentanone. } \\
\text { Nylon } 6 / 12 \text { and nylon } 12 \text { were } \\
\text { less reactive, only traces of } \\
\text { monomer were observed }\end{array}$ & $\begin{array}{l}\text { HHV of oil from algae } \\
33 \mathrm{MJ} / \mathrm{kg}, \mathrm{HHV} \text { of oil } \\
\text { from algae+ nylon } \\
28-35 \mathrm{MJ} / \mathrm{kg}\end{array}$ & [49] \\
\hline
\end{tabular}

\subsection{Hydrothermal Liquefaction of Polymers and Their Mixtures}

Pedersen and Conti [42] assessed the prospects of using the HTL process for processing nine types of solid polymers, including polybutylene terephthalate, polycarbonate, polyethylene terephthalate, polylactate, polymethyl methacrylate, polyoxymethylene, styrene butadiene, polyvinyl acetate, and polyphenylene oxide.

The process was carried at the temperature of $400{ }^{\circ} \mathrm{C}$ and pressure of $25 \mathrm{MPa}$ for $15 \mathrm{~min}$ and the mass dose of raw materials was $10 \%$. The polymers have shown that they are readily degraded in the HTL process, with the formation of water-soluble organic compounds, biofuels, gaseous products, and a solid residue. Figure 2 shows the average oil and solid matter yield for each polymer [42]. Analysis of the data establishes that the processing of a typical representative of marine debris, polyethylene terephthalate, even under supercritical conditions $\left(400{ }^{\circ} \mathrm{C}, 25 \mathrm{MPa}\right)$ did not lead to the formation of a liquid fraction, almost the entire volume of carbon passed into a solid phase (biochar). Good fuel yield was obtained during processing of polycarbonate, styrene butadiene, and polyphenylene oxide, but the proportion of these polymers in marine debris is negligible. 


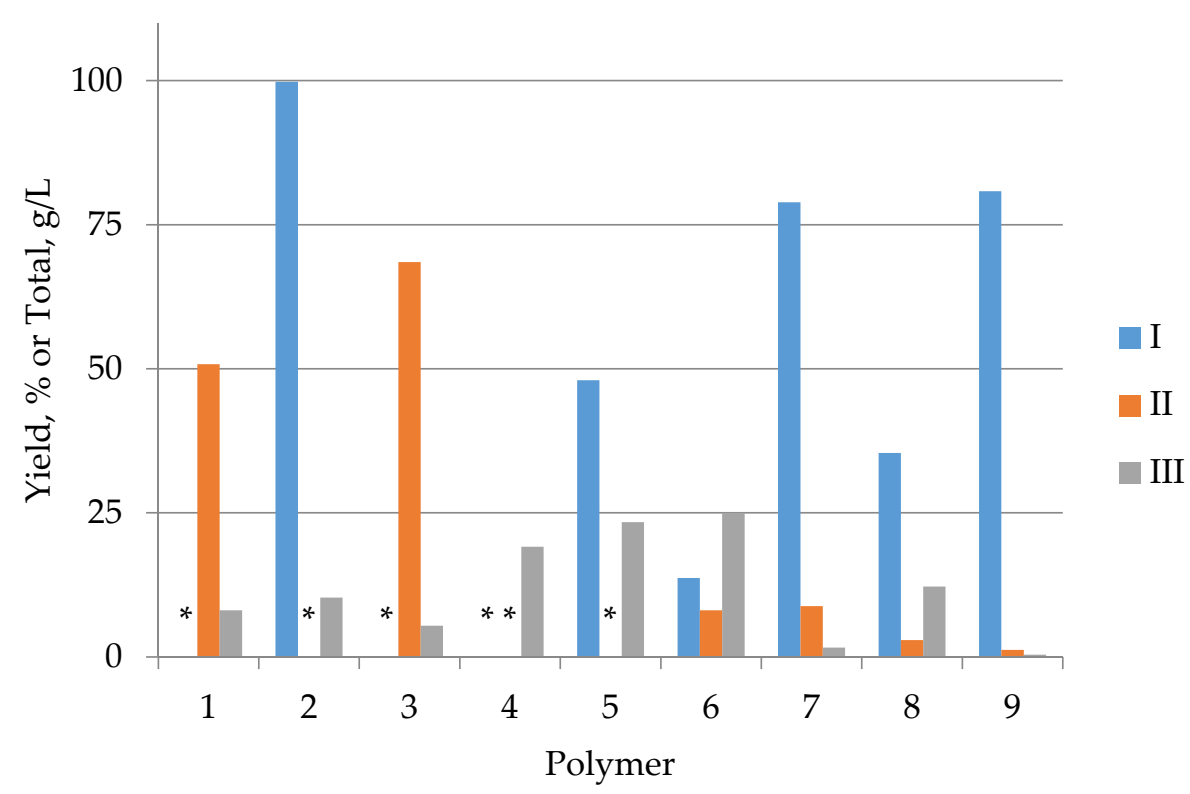

Figure 2. The results of polymer processing by the hydrothermal liquefaction: I-oil yield, \%; II-Solid Phase Yield, \%; III-Total Organic Carbon in the Aqueous Phase, g/L. Plymers: 1-Polybutylene terephthalate; 2-Polycarbonate; 3-PET; 4-Polylactate; 5-Polymethyl methacrylate; 6-Polyoxymethylene; 7-Polyphenylene oxide; 8-Polyvinyl acetate; 9-Styrene butadiene. *-no data.

Jin et al. [43] studied in detail the effect of temperature and reaction time on the degradation of polyethylene. As a result of the study, it was found that during the process (up to $4 \mathrm{~h}$ ) at temperatures below $400{ }^{\circ} \mathrm{C}$, the formation of liquid biofuel did not occur. At a temperature of $425{ }^{\circ} \mathrm{C}$, the total yield of fuel and paraffins varied from $69 \%$ to $87 \%$, reaching a maximum at a process time of $2.5 \mathrm{~h}$. With time increase the yield of the gas phase increased from $1 \%$ to $21 \%$ at process times of 1 and $4 \mathrm{~h}$, respectively. At $450{ }^{\circ} \mathrm{C}$, a similar maximum fuel yield was achieved with a process time of $45 \mathrm{~min}$.

Another research group obtained the maximum yield (97 $\mathrm{wt} \%$ ) of paraffinic and $\alpha-$ olefin waxes mixture during the HTL processing of polyethylene at $425^{\circ} \mathrm{C}$ and a reaction time of 30-40 min, while the solid fraction all experiments was not found [42].

Jin et al. processed polypropylene at a temperature of $425^{\circ} \mathrm{C}$ and achieved a fuel yield of $91 \mathrm{wt} \%$ after $2 \mathrm{~h}$, which indicates a faster conversion of PP than from PE. The polypropylene fuel contained more olefins and cycloparaffins (about $90 \mathrm{wt} \%$ ) and less paraffins (about $10 \mathrm{wt} \%$ ) [44].

A research group from Xi'an University of Technology processed Tetrapak at different temperatures and found that the bio-oil yield increased from $4.56 \%$ to $24.34 \%$ when the temperature was raised from $300{ }^{\circ} \mathrm{C}$ to $360^{\circ} \mathrm{C}$. However, temperatures above $360^{\circ} \mathrm{C}$ had some negative impacts on bio-oil yield. This is mainly due to the following: firstly, the higher temperature promoted the gasification reaction; secondly, at higher temperatures, polyethylene will envelop the paper, reducing porosity and preventing heat and mass transfer [45].

A research group from Aarhus University evaluated the prospects of using the HTL process for processing a wide range of polymers [46]. The process was carried out at $350{ }^{\circ} \mathrm{C}$ for $14 \mathrm{~min}$ in the presence of a $\mathrm{KOH}$ catalyst of $17.2 \mathrm{~g} / \mathrm{L}$. The main findings of the study regarding polymers typical of marine debris can be summarized as follows:

1. PET behaved very different from others, since upon addition of a catalyst the formed insoluble terephthalic acid transformed into a soluble salt, increasing the COD of the aqueous phase [46].

2. PVC was the only polymer that exhibited carbonization reactions rather than liquefaction reactions. The addition of alkali did not lead to significant differences in the 
yields of oil and char; however, a large difference was noted in the volumes of the gas phase. Treatment of PVC in the presence of alkali gives an increased gas yield due to the release of $\mathrm{Cl}_{2}$ amount. Solid residues of PVC were strongly dechlorinated, which indicates that this fraction can be further used as a carbon source [46].

3. In general, each type of synthetic polymer exhibits its own depolymerization characteristics at HTL, which creates opportunities and challenges for future applications for net and mixed streams. Short exposure time of subcritical HTL was not efficient for polyolefins and polystyrene, however it could be useful for polymers, which contain heteroatoms.

A group of scientists from Pennsylvania State University assessed the effect of the processing time $(0.5 \mathrm{~h}, 1 \mathrm{~h})$ and temperature $\left(350-450{ }^{\circ} \mathrm{C}\right)$ on the yield, composition, and quality of oil obtained as a result of HTL of polypropylene, polystyrene, polycarbonate and polyethylene terephthalate. The maximum oil yield for each material varied from $16 \mathrm{wt} \%$ for PET to $86 \mathrm{wt} \%$ for polystyrene. Depolymerization of plastics occurred fastest in supercritical water $\left(\mathrm{T}>400^{\circ} \mathrm{C}\right)$. Longer reaction times and higher supercritical temperatures reduce the fuel yield but increase its calorific value (HHV) [47].

\subsection{Joint Hydrothermal Liquefaction of Polymers and Biomass}

Joint processing of pistachio shells and a mixture of the four most common polymers (PET, polyethylene, polypropylene, and nylon) caused an increase of solid yields compared to HTL of pure pistachio shells. Co-processing of polyethylene and polypropylene decreased oil yield from $34.1 \%$ to $20.4 \%$ and from $34.1 \%$ to $30.7 \%$. The yield of bio-oil during processing with PET remained practically unchanged, while the yield of char increased by a multiple of the number of added polymers [88].

Unlike other plastics, the increase in biochar yield was much less when pistachio shells were co-liquefied with nylon (the maximum solids increase was $9 \%$ with the addition of $20 \%$ polymer). The biofuel yield for nylon mixes was almost the same and amounted to $30.0 \%$, while a significant change in the composition of the aqueous phase was observed. This behavior of nylon has been confirmed by other studies [88] and is associated with the transformation of nylon during HTL processing into water-soluble caprolactam.

The co-processing of pistachio shells with a mixture of plastics in equal proportions led to a significant increase in bio-char production, while the bio-oil yield decreased by $20 \%$. This fact, according to the authors, confirmed the lack of expediency with the joint processing of biomass and polymers regarding bio-oil production.

Savage et al. [90] studied the synergistic effect of the combined processing of cellulose, starch, soy protein isolate, lignin, stearic acid, glucose, and various polymers, including polypropylene, polystyrene, polycarbonate, and polyethylene terephthalate. They found that the combined processing of cellulose, starch, and lignin with plastics provided an increase in the fuel yield by $13.9 \mathrm{wt} \%\left(\right.$ at $300{ }^{\circ} \mathrm{C}, 30 \mathrm{~min}$ ). It was also established that polyolefins were activated during the joint processing of these components, which ensured a decrease in the temperature of their decomposition.

When processing the biomass of shrubs and a mixture of polyolefin waste, it was found that there was a synergistic effect that provided an increase in the average fuel yield from $40 \%$ to $50 \%$. The addition of $3 \mathrm{wt} \%$ catalyst (bentonite clay activated with hydrochloric acid) provided the maximum bio-oil yield- $61.23 \mathrm{wt} \%$ (temperature $420{ }^{\circ} \mathrm{C}$ for a mixture of three parts of biomass: one part polymer, holding time $60 \mathrm{~min}$ ) [89].

There is little research on the co-processing of macroalgae with polymers typical of marine debris. Detailed studies assessing the effect of several of the most common polymer contaminants (polyethylene, PET, polypropylene, nylon) on the hydrothermal liquefaction (HTL) process of four species of macroalgae (L. digitata, U. lactuca, F. serratus, and S. muticum) were carried out by Raikova et al. [51].

The biomass to polymer ratios were 100:0, 90:10, 75:25, 50:50, and 0:100. The process was carried out at a temperature of $(340 \pm 3){ }^{\circ} \mathrm{C}$, the reaction time was $12-27 \mathrm{~min}$, and the pressure inside the reactor was $15 \mathrm{MPa}$. It was found that polyethylene and propylene 
practically did not decompose under the influence of subcritical water. The presence of all types of plastics in the processed biomass resulted in a moderate synergistic effect which led to an increase in the amount of carbon in biofuels, a decrease in nitrogen content, and an increase in heating value. Nylon (fishing nets) was depolymerized almost completely under the HTL process to form caprolactam, which entered mainly into the aqueous phase. Disadvantageous for biofuel production, the disposal of marine nylon debris to produce monomers still could be a promising source of income for future biofuel plants [49].

To summarize, it can be seen from the results of joint processing of polymers and various types of biomasses that polymers transformed at higher temperatures than biomas $[47,89,90]$. The addition of polymers does not increase, but rather decreases the yield of biofuels and increases the yield of char, which is undesirable. Thus, the presence of polymers in the biomass of drifting macroalgae should be regarded as a ballast fraction, which, in the case of significant content, can have a negative effect on the process.

\section{Discussion}

This paper analyzes macroalgae composition. It was found that macroalgae are carbohydrate-rich (concentration varies from $43-50 \%$ d.m.) due to their cellulose and hemicellulose contents in the cell wall. This leads to macroalgae having a lower bio-crude yield compared to the microalgae, which are richer in lipids (average content is four times higher). Due to a high content of carbohydrates, excessive organic acids are formed during the HTL process and decrease the $\mathrm{pH}$. Acidic conditions during HTL cause a shift towards solid products rather than oil [31].

From an economic and technological point of view, hydrothermal liquefaction technology has been recognized as promising for the transformation of the wet biomass of macroalgae since it does not require preliminary drying of the biomass.

Five key points were established based on a comprehensive analysis of the conditions and efficiency of macroalgae hydrothermal liquefaction:

- The recommended process temperature for pure algae without the use of catalytic systems is $260-280^{\circ} \mathrm{C}$, which provides a maximum biofuel yield up to $16 \%[27,61,63]$.

- Maximum oil yield during the HTL process could be achieved by using alcohols as co-solvents, since the presence of alcohols leads to an esterification reaction with carboxylic acids [31];

- As catalytic systems, it is worth paying attention to heterogeneous catalysis with the use of mineral and metal-containing catalysts, which provide an increase in the bio-oil yield and "soften" the conditions of the process.

- The presence of polymers, typical representatives of marine waste (TeraPak, high- and low-pressure polyethylene, polypropylene, and nylon) do not provide a significant synergistic effect, and with a significant proportion of polymers in the macroalgae biomass (more than $10 \%$ by weight in terms of dry matter), an increase in the yield of non-target solid fraction and a decrease in the yield of biofuel should be expected;

- Optimum process temperatures, providing the maximum yield of liquid fraction, for most polymers are in the range of $350-400{ }^{\circ} \mathrm{C}$, while for macroalgae the optimum temperature is in the range of $260-290^{\circ} \mathrm{C}$.

The organization of a cascade process, including the production of a number of valuable components (proteins, vitamins, pigments, biologically active substances) with the subsequent processing of residual biomass into liquid fuel, should be considered the most promising direction for optimizing the technology for processing macroalgae biomass, which meets modern principles of circular economy and resource management. However, additional practical research is needed to assess the effect of impurities on the quality and quantity of recovered components from drifting algae. Without a doubt, solid residue can be included in the resource cycle as a sorbent or bio-char.

The advantages of using a two-stage process for the processing of contaminated biomass are also not obvious since the advantages are clear only when valuable components are extracted in the first stage. If there is no such task, then the two-stage treatment will 
only lead to a decrease in the fuel yield. Assessment of potential consumers of synthetic oil will make it possible to understand the need for preliminary extraction of proteins and carbohydrates to control the quality of oil (nitrogen, oxygen, and HHV content).

Author Contributions: Conceived and designed the research-Y.K., O.B. and N.S.; analyzed and interpreted the data-Y.K., S.I. and N.S.; contributed reagents, materials, analysis tools or data-Y.K., S.S. and N.S.; wrote the paper-Y.K., O.B., S.I. and N.S. All authors have read and agreed to the published version of the manuscript.

Funding: This research was funded by the Ministry of Science and Higher Education of the Russian Federation, project number FZWM-2021-0016.

Institutional Review Board Statement: Not applicable.

Informed Consent Statement: Not applicable.

Data Availability Statement: Not applicable.

Conflicts of Interest: The authors declare no conflict of interest.

\section{References}

1. Joniver, C.F.H.; Photiades, A.; Moore, P.J.; Winters, A.L.; Woolmer, A.; Adams, J.M.M. The global problem of nuisance macroalgal blooms and pathways to its use in the circular economy. Algal Res. 2021, 58, 102407. [CrossRef]

2. Ingle, K.; Vitkin, E.; Robin, A.; Yakhini, Z.; Mishori, D.; Golberg, A. Macroalgae Biorefinery from Kappaphycus alvarezii: Conversion Modeling and Performance Prediction for India and Philippines as Examples. Bioenerg. Res. 2018, 11, 22-32. [CrossRef]

3. Stepanova, E.M.; Lugovaya, E.A. Macro- and microelements in some species of marine life from the Sea of Okhotsk. Foods Raw Mater. 2021, 9, 302-309. [CrossRef]

4. Tabakaev, A.V.; Tabakaeva, O.V.; Piekoszewski, W.; Kalenik, T.K.; Poznyakovsky, V.M. Antioxidant properties of edible sea weed from the Northern Coast of the Sea of Japan. Foods Raw Mater. 2021, 9, 262-270. [CrossRef]

5. Del Río, P.G.; Domínguez, E.; Domínguez, V.D.; Romaní, A.; Domingues, L.; Garrote, G. Third generation bioethanol from invasive macroalgae Sargassum muticum using autohydrolysis pretreatment as first step of a biorefinery. Renew. Energy 2019, 141, 728-735. [CrossRef]

6. Tedesco, S.; Stokes, J. Valorisation to biogas of macroalgal waste streams: A circular approach to bioproducts and bioenergy in Ireland. Chem. Pap. 2017, 71, 721-728. [CrossRef] [PubMed]

7. Tedesco, S.; Daniels, S. Optimisation of biogas generation from brown seaweed residues: Compositional and geographical parameters affecting the viability of a biorefinery concept. Appl. Energy 2018, 228, 712-723. [CrossRef]

8. Torres, M.D.; Kraan, S.; Domínguez, H. Seaweed biorefinery. Rev. Environ. Sci. Biotechnol. 2019, 18, 1-54. [CrossRef]

9. Álvarez-Viñas, M.; Flórez-Fernández, N.; Torres, M.D.; Domínguez, H. Successful Approaches for a Red Seaweed Biorefinery. Mar. Drugs 2019, 17, 620. [CrossRef]

10. Flórez-Fernández, N.; Domínguez, H.; Torres, M.D. Advances in the biorefinery of Sargassum muticum: Valorisation of the alginate fractions. Ind. Crops Prod. 2019, 138, 111483. [CrossRef]

11. European Parliament; Council of the European Union. Directive (EU) 2018/2001 of the European Parliament and of the Council of 11 December 2018 on the Promotion of the Use of Energy from Renewable Sources: PE/48/2018/REV/1. Off. J. Eur. Union 2018, 328, 1-20.

12. Kargbo, H.; Harris, J.S.; Phan, N.A. Dropin-fuel production from biomass Critical review on technoeconomic feasibility and sustainability Renewable-and-Sustainable-Energy-Reviews. Renew. Sustain. Energy Rev. 2021, 135, 110168. [CrossRef]

13. Marulanda, V.A.; Botero Gutierrez, C.D.; Cardone Alzate, C.A. Thermochemical Biological Biochemical, and Hybrid Conversion Methods of Bio-Derived Molecules into Renewable Fuels. In Advanced Bioprocessing for Alternative Fuels, Biobased Chemicals, and Bioproducts; Hosseini, M., Ed.; Elsevier: Duxford, UK, 2019; pp. 59-81. [CrossRef]

14. Huang, S.; Liu, T.; Peng, B.; Geng, A. Enhanced ethanol production from industrial lignocellulose hydrolysates by a hydrolysatecofermenting Saccharomyces cerevisiae strain. Bioproc. Biosyst. Eng. 2019, 42, 883-896. [CrossRef]

15. Rech, F.R.; Fontana, R.C.; Rosa, C.A.; Camassola, M.; Ayub, M.A.Z.; Dillon, A.J. Fermentation of hexoses and pentoses from sugarcane bagasse hydrolysates into ethanol by Spathaspora hagerdaliae. Bioproc. Biosyst. Eng. 2019, 42, 83-92. [CrossRef]

16. Zhu, L.; Li, P.; Sun, T.; Kong, M.; Li, X.; Ali, S.; Liu, W.; Fan, S.; Qiao, J.; Li, S.; et al. Overexpression of SFA1 in engineered Saccharomyces cerevisiae to increase xylose utilization and ethanol production from different lignocellulose hydrolysates. Bioresour. Technol. 2020, 313, 123724. [CrossRef] [PubMed]

17. Rajak, C.; Jacob, S.; Kim, B.S. A holistic zero waste biorefinery approach for macroalgal biomass utilization: A review. Sci. Total Environ. 2020, 716, 137067. [CrossRef] [PubMed]

18. Brex'o, R.P.; Sant'Ana, A.S. Impact and significance of microbial contamination during fermentation for bioethanol production. Renew. Sustain. Energ. Rev. 2017, 73, 423-434. [CrossRef] 
19. Winjobi, O.; Shonnard, D.R.; Bar-Ziv, E.; Zhou, W. Techno-economic assessment of the effect of torrefaction on fast pyrolysis of pine. Biofuels Bioprod. Biorefin. 2016, 10, 117-128. [CrossRef]

20. Brigljevic, B.; Liu, J.; Lim, H. Comprehensive feasibility assessment of a polygeneration process integrating fast pyrolysis of $S$. japonica and the Rankine cycle. Appl. Energy 2019, 254, 113704. [CrossRef]

21. Brilman, D.W.F.; Drabik, N.; Wądrzyk, M. Hydrothermal co-liquefaction of microalgae, wood, and sugar beet pulp. Biomass Convers. Biorefin. 2017, 7, 445-454. [CrossRef]

22. Ciuffi, B.; Loppi, M.; Rizzo, A.M.; Chiaramonti, D.; Rosi, L. Towards a better understanding of the HTL process of lignin-rich feedstock. Sci. Rep. 2021, 11, 15504. [CrossRef] [PubMed]

23. Ellersdorfer, M. Hydrothermal co-liquefaction of chlorella vulgaris with food processing residues, green waste and sewage sludge. Biomass Bioenergy 2020, 142, 105796. [CrossRef]

24. Yang, J.; Quan, H.Q.S.; Corscadden, K.; Niu, H.; Lin, J.; Astatkie, T. Advanced models for the prediction of product yield in hydrothermal liquefaction via a mixture design of biomass model components coupled with process variables. Appl. Energy 2019, 233, 906-915. [CrossRef]

25. Koley, S.; Khadase, M.S.; Mathimani, T.; Raheman, H.; Mallick, N. Catalytic and non-catalytic hydrothermal processing of Scenedesmus obliquus biomass for bio-crude production-A sustainable energy perspective. Energy Convers. Manag. 2018, 163, 111-121. [CrossRef]

26. Han, Y.; Hoekman, K.; Jena, U.; Das, P. Use of Co-Solvents in Hydrothermal Liquefaction (HTL) of Microalgae. Energies 2020, 13, 124. [CrossRef]

27. Nazari, L.; Yuan, Z.; Ray, M.B.; Xu, C. Co-conversion of waste activated sludge and sawdust through hydrothermal liquefaction: Optimization of reaction parameters using response surface methodology. Appl. Energy 2017, 203, 1-10. [CrossRef]

28. Arun, J.; Gopinath, K.P.; Selvam, P.; Rajan, S.; Malolan, R.; Srinivaasan, P. Hydrothermal liquefaction and pyrolysis of Amphiroa fragilissima biomass: Comparative study on oxygen content and storage stability parameters of bio-oil. Bioresour. Technol. 2020, 11, 100465. [CrossRef]

29. Greene, J.M.; Gulden, J.; Wood, G.; Huesemann, M.; Quinn, J.C. Techno-economic analysis and global warming potential of a novel offshore macroalgae biorefinery. Algal Res. 2020, 51, 102032. [CrossRef]

30. Matayeva, A.; Basile, F.; Cavani, F.; Bianchi, D.; Chiaberge, S. Development of Upgraded Bio-Oil via Liquefaction and Pyrolysis. Studies in Surface Science and Catalysis. In Horizons in Sustainable Industrial Chemistry and Catalysis Studies in Surface Science and Catalysis; Albonetti, S., Perathoner, S., Quadrelli, E.A., Eds.; Elsevier: Oxford, UK, 2019; Volume 178, pp. 231-256. [CrossRef]

31. Basar, I.A.; Liu, H.; Carrere, H.; Trably, E.; Eskicioglu, C. A review on key design and operational parameters to optimize and develop hydrothermal liquefaction of biomass for biorefinery applications. Green Chem. 2021, 23, 1404. [CrossRef]

32. Ou, L.; Thilakaratne, R.; Brown, R.C.; Wright, M.M. Techno-economic analysis of transportation fuels from defatted microalgae via hydrothermal liquefaction and hydroprocessing. Biomass Bioenergy 2015, 72, 45-54. [CrossRef]

33. Aierzhati, A.; Watson, J.; Si, B.; Stablein, M.; Wang, T.; Zhang, Y. Development of a mobile, pilot scale hydrothermal liquefaction reactor: Food waste conversion product analysis and techno-economic assessment. Energy Convers. Manag. 2021, 10, 100076. [CrossRef]

34. Yang, C.; Wu, J.; Deng, Z.; Zhang, B.; Cui, C.; Ding, Y. A comparison of energy consumption in hydrothermal liquefaction and pyrolysis of microalgae. Trends Renew. Energy 2017, 3, 76-85. [CrossRef]

35. Sun, X.; Liang, J.; Zhu, M.; Zhao, Y.; Zhang, B. Microplastics in seawater and zooplankton from the Yellow Sea. Environ. Pollut. 2018, 242, 585-595. [CrossRef]

36. Zhang, K.; Shi, H.; Peng, J.; Wang, Y.; Wu, X.X.C.; Lam, P.K.S. Microplastic pollution in China's inland water systems: A review of findings, methods, characteristics, effects, and management. Sci. Total Environ. 2018, 630, 1641-1653. [CrossRef]

37. Barboza, L.G.A.; Vethaak, A.D.; Lavorante, B.R.B.O.; Lundebye, A.-K.; Guilhermino, L. Marine microplastic debris: An emerging issue for food security, food safety and human health. Mar. Pollut. Bull. 2018, 133, 336-348. [CrossRef]

38. Rhinane, H.; Houssa, R.; Loulad, S. The seafloor marine debris on the north and the central part of the moroccan atlantic waters from tangier $\left(35^{\circ} \mathrm{n}\right)$ to sidi ifni $\left(29^{\circ} \mathrm{n}\right)$ : Composition, abundance, spatial distribution, sources and movement. ISPRS 2019, 42, 377-384. [CrossRef]

39. Nurhayati, E.; Tangahu, B.V.; Mahardini, I.R.; Berlianto, M.; Yuliawati, A.A. Marine Debris Monitoring in the Coastal Area of the District of Banyuwangi, Indonesia: Characterization of the Debris Type and composition. In IOP Conference Series: Earth and Environmental Science, Proceedings of the Sustainability and Resilience of Coastal Management, Surabaya, Indonesia, 30 November 2020; IOP Publishing: Bristol, UK, 2021; Volume 799, p. 012039. [CrossRef]

40. Iñiguez, M.E.; Conesa, J.A.; Fullana, A. Hydrothermal carbonization (HTC) of marine plastic debris. Fuel 2019, $257,116033$. [CrossRef]

41. Tang, Z.; Fiorilli, S.; Heeres, H.; Pescarmona, P. Multifunctional Heterogeneous Catalysts for the Selective Conversion of Glycerol into Methyl Lactate. ACS Sustain. Chem. Eng. 2018, 6, 10923-10933. [CrossRef]

42. Helmer Pedersen, T.; Conti, F. Improving the circular economy via hydrothermal processing of high-density waste plastics. Waste Manag. 2017, 68, 24-31. [CrossRef]

43. Jin, K.; Vozka, P.; Kilaz, G.; Chen, W.-T.; Wang, N.-H.L. Conversion of polyethylene waste into clean fuels and waxes via hydrothermal processing (HTP). Fuel 2020, 273, 117726. [CrossRef] 
44. Jin, K.; Vozka, P.; Gentilcore, C.; Kilaz, G.; Wang, N.-H.L. Low-pressure hydrothermal processing of mixed polyolefin wastes into clean fuels. Fuel 2021, 294, 120505. [CrossRef]

45. Wang, Y.; Zhu, Y.; Liu, Z.; Su, J.; Fang, C.; Xu, D.; Song, W.; Wangb, S. Influences of operating parameters on liquefaction performances of Tetra Pak in sub-/supercritical water. J. Environ. Manag. 2019, 237, 545-551. [CrossRef] [PubMed]

46. Passos, J.S.; Glasius, M.; Biller, P. Screening of common synthetic polymers for depolymerization by subcritical hydrothermal liquefaction. Process Saf. Environ. Prot. 2020, 139, 371-379. [CrossRef]

47. Seshasayee, M.S.; Savage, P.E. Oil from plastic via hydrothermal liquefaction: Production and characterization. Appl. Energy 2020, 278, 115673. [CrossRef]

48. Ciuffi, B.; Rosi, L.; Miliotti, E.; Lotti, G.; Rizzo, A.M.; Chiaramonti, D. Batch Hydrothermal liquefaction of end-of-life plastic and oil characterization. E3S Web Conf. 2021, 238, 08004. [CrossRef]

49. Hongthong, S.; Leese, H.S.; Allen, M.J.; Chuck, C.J. Assessing the Conversion of Various Nylon Polymers in the Hydrothermal Liquefaction of Macroalgae. Environments 2021, 8, 34. [CrossRef]

50. Gu, J.S.; Martinez-Fernandez, N.; Pang, X.; Fu, S.C. Recent development of hydrothermal liquefaction for algal biorefinery. Renew. Sust. Energ. Rev. 2020, 121, 109707. [CrossRef]

51. Raikova, S.; Knowles, T.D.J.; Allen, M.J.; Christopher, J.; Chuck, C.J. Co-liquefaction of macroalgae with common marine plastic Pollutants. ACS Sustain. Chem. Eng. 2019, 7, 6769-6781. [CrossRef]

52. Takolander, A.; Cabeza, M.; Leskinen, E. Climate change can cause complex responses in Baltic Sea macroalgae: A systematic review. J. Sea Res. 2017, 123, 16-29. [CrossRef]

53. Andreeva, A.; Budenkova, E.; Babich, O.; Sukhikh, S.; Dolganyuk, V.; Michaud, P.; Ivanova, S. Influence of Carbohydrate Additives on the Growth Rate of Microalgae Biomass with an Increased Carbohydrate Content. Mar. Drugs 2021, $19,381$. [CrossRef]

54. Andreeva, A.; Budenkova, E.; Babich, O.; Sukhikh, S.; Ulrikh, E.; Ivanova, S.; Prosekov, A.; Dolganyuk, V. Purification, and Study of the Amino Acid Composition of Microalgae Proteins. Molecules 2021, 26, 2767. [CrossRef]

55. Balina, K.; Romagnoli, F.; Pastare, L.; Blumberga, D. Use of macroalgae for bioenergy production in Latvia: Review of potential availability of marine coastline species. Energy Procedia 2017, 113, 403-410. [CrossRef]

56. Jatmiko, T.H.; Prasetyo, D.J.; Hernawan, C.D.; Khasanah, M.Y. Nutritional Evaluation of Ulva sp. from Sepanjang Coast, Gunungkidul, Indonesia. In IOP Conference Series: Earth and Environmental Science, Proceedings of the 2nd International Conference on Natural Products and Bioresource Science-2018, Tangerang, Indonesia, 1-2 November 2018; IOP Publishing: Bristol, UK, 2019; Volume 251, p. 012011. [CrossRef]

57. Schultz-Jensen, N.; Thygesen, A.; Leipold, F.; Thomsen, S.T.; Roslander, C.; Lilholt, H.; Bjerre, A.B. Pretreatment of the macroalgae Chaetomorpha linum for the production of bioethanol-Comparison of five pretreatment technologies. Bioresour. Technol. 2013, 140, 36-42. [CrossRef]

58. Abomohra, E.-F.; El-Naggar, A.; Hamed, A.; Ali, B.A. Potential of macroalgae for biodiesel production: Screening and evaluation studies. J. Biosci. Bioeng. 2018, 125, 231-237. [CrossRef] [PubMed]

59. Neveux, N.; Yuen, A.; Jazrawi, C.; Magnusson, M.; Haynes, B.; Masters, A.; Montoya, A.; Paul, N.; Maschmeyer, T.; de Nys, R. Biocrude yield and productivity from the hydrothermal liquefaction of marine and freshwater green macroalgae. Bioresour. Technol. 2014, 155, 334-341. [CrossRef] [PubMed]

60. Neveux, N.; Magnusson, M.; Maschmeyer, T.; Nys, R.; Paul, N.A. Comparing the potential production and value of high-energy liquid fuels and protein from marine and freshwater macroalgae. GCB Bioenergy 2015, 7, 673-689. [CrossRef]

61. Biswas, B.; Fernandes, A.C.; Kumar, J.; Muraleedharan, U.D.; Bhaskar, T. Valorization of Sargassum tenerrimum: Value addition using hydrothermal liquefaction. Fuel 2018, 222, 394-401. [CrossRef]

62. Elliott, D.C.; Hart, T.R.; Neuenschwander, G.G.; Rotness, L.J.; Roesijadi, G.; Zacher, A.H.; Magnuson, J.K. Hydrothermal Processing of Macroalgal Feedstocks in Continuous-Flow Reactors. ACS Sustain. Chem. Eng. 2014, 2, 207-215. [CrossRef]

63. Fernandes, A.C.; Biswas, B.; Kumar, J.; Bhaskar, T.; Muraleedharan, U.D. Valorization of the red macroalga Gracilaria corticata by hydrothermal liquefaction: Product yield improvement by optimization of process parameters. Bioresour. Technol. 2021, 15 [CrossRef]

64. Yuan, C.; Wang, S.; Cao, B.; Hu, Y.; Abomohra, E.-F.; Wang, Q.; Qian, L.; Liu, L.; Liu, X.; He, Z.; et al. Optimization of hydrothermal co-liquefaction of seaweeds with lignocellulosic biomass: Merging 2nd and 3rd generation feedstocks for enhanced bio-oil production. Energy 2019, 173, 413-422. [CrossRef]

65. He, Y.T.; Liang, X.; Jazrawi, C.; Montoya, A.; Yuen, A.K.; Cole, A.J.; Neveux, N.; Paul, N.A.; Nys, R.D.; Maschmeyer, T.; et al. Continuous hydrothermal liquefaction of macroalgae in the presence of organic co-solvents. Algal Res.-Biomass Biofuels Bioprod. 2016, 17, 185-195. [CrossRef]

66. Yuan, C.; Wang, S.; Qian, L.; Barati, B.; Gong, X.; Abomohra, A.E.F.; Wang, X.; Esakkimuthu, S.; Hu, Y.; Liu, L. Effect of cosolvent and addition of catalyst (HZSM-5) on hydrothermal liquefaction of macroalgae. Int. J. Energy Res. 2019, 43, 8841-8851. [CrossRef]

67. Li, Y.; Zhu, C.; Jiang, J.; Yang, Z.; Feng, W.; Li, L.; Guo, Y.; Hu, J. Catalytic hydrothermal liquefaction of Gracilaria corticata macroalgae: Effects of process parameter on bio-oil up-gradation. Bioresour. Technol. 2021, 319, 124163. [CrossRef] [PubMed]

68. Biswas, B.; Kumar, A.; Fernandes, A.C.; Saini, K.; Negi, S.; Muraleedharan, U.D.; Bhaskar, T. Solid base catalytic hydrothermal liquefaction of macroalgae: Effects of process parameter on product yield and characterization. Bioresour. Technol. 2020, 307, 123232. [CrossRef] [PubMed] 
69. Zhang, B.; Chen, H.; He, Z. Catalytic hydrothermal liquefaction of Spirulina platensis: Focusing on aqueous phase characterization. Int. J. Energy Res. 2019, 43, 7135-7145. [CrossRef]

70. Yan, L.; Wang, Y.; Li, J.; Zhang, Y.; Ma, L.; Fu, F.; Chen, B.; Liu, H. Hydrothermal liquefaction of Ulva prolifera macroalgae and the influence of base catalysts on products. Bioresour. Technol. 2019, 292, 121286. [CrossRef]

71. Li, D.; Chen, L.; Xu, D.; Zhang, X.; Ye, N.; Chen, F.; Chen, S. Preparation and characteristics of bio-oil from the marine brown alga Sargassum patens C. Agardh. Bioresour. Technol. 2012, 104, 737-742. [CrossRef]

72. Nguyen, S.T.; Le, T.M.; Nguyen, H.V. Iron-catalyzed fast hydrothermal liquefaction of Cladophora socialis macroalgae into high quality fuel precursor. Bioresour. Technol. 2021, 337, 125445. [CrossRef] [PubMed]

73. Ma, C.; Geng, J.; Zhang, D.; Ning, X. Hydrothermal liquefaction of macroalgae: Influence of zeolites based catalyst on products. J. Energy Inst. 2020, 93, 581-590. [CrossRef]

74. Kandasamy, S.; Zhang, B.; He, Z.; Chen, H.; Feng, H.; Wang, Q.; Wang, B.; Ashokkumar, V.; Siva, S.; Bhuvanendran, N.; et al. Effect of low-temperature catalytic hydrothermal liquefaction of Spirulina platensis. Energy 2020, 190, 116236. [CrossRef]

75. Kandasamy, S.; Zhang, B.; He, Z.; Chen, H.; Feng, H.; Wang, Q.; Wang, B.; Bhuvanendran, N.; Esakkimuthu, S.; Ashokkumar, V.; et al. Hydrothermal liquefaction of microalgae using $\mathrm{Fe}_{3} \mathrm{O}_{4}$ nanostructures as efficient catalyst for the production of bio-oil: Optimization of reaction parameters by response surface methodology. Biomass Bioenergy 2019, 131, 105417. [CrossRef]

76. Suganya, T.; Varman, M.; Masjuki, H.H.; Renganathan, S. Macroalgae and microalgae as a potential source for commercial applications along with biofuels production: A biorefinery approach. Renew. Sustain. Energ. Rev. 2016, 55, 909-941. [CrossRef]

77. Chen, H.; Zhong, Q. Thermal and UV stability of $\beta$-carotene dissolved in peppermint oil microemulsified by sunflower lecithin and Tween 20 blend. Food Chem. 2015, 174, 630-636. [CrossRef] [PubMed]

78. Costanzo, W.; Hilten, R.; Jena, U.; Das, K.C.; Kastner, J.R. Effect of low temperature hydrothermal liquefaction on catalytic hydrodenitrogenation of algae biocrude and model macromolecules. Algal Res. 2016, 13, 53-68. [CrossRef]

79. Hockstad, R.; Obeid, W.; Hatcher, P.G.; Savage, P.E. The Use of Hydrothermal Carbonization to Recycle Nutrients in Algal Biofuel Production. Environ. Prog. Sustain. Energy 2013, 32, 5235-5243.

80. Jazrawi, C.; Biller, P.; He, Y.; Montoya, A.; Ross, A.B.; Maschmeyer, T.; Haynes, B.S. Two-stage hydrothermal liquefaction of a high-protein microalga. Algal Res. 2015, 8, 15-22. [CrossRef]

81. European Comission. Sustainable Agriculture, Forestry and Fisheries in the Bioeconomy. A Challenge for Europe; Publications Office of the European Union: Brussels, Belgium, 2015. [CrossRef]

82. Cesario, M.T.; da Fonseca, M.M.R.; Marques, M.M.; de Almeida, M.C.M. Marine algal carbohydrates as carbon sources for the production of biochemicals and biomaterials. Biotechnol. Adv. 2018, 36, 798-817. [CrossRef]

83. Miao, C.; Chakraborty, M.; Chen, S. Impact of reaction conditions on the simultaneous production of polysaccharides and bio-oil from heterotrophically grown Chlorella sorokiniana by a unique sequential hydrothermal liquefaction process. Bioresour. Technol. 2012, 110, 617-627. [CrossRef]

84. Chakraborty, M.; Miao, C.; McDonald, A.; Chen, S. Concomitant extraction of bio-oil and value added polysaccharides from Chlorella sorokiniana using a unique sequential hydrothermal extraction technology. Fuel 2012, 95, 63-70. [CrossRef]

85. Prapaiwatcharapan, K.; Sunphorka, S.; Kuchonthara, P.; Kangvansaichol, K.; Hinchiranan, N. Single-and two-step hydrothermal liquefaction of microalgae in a semi-continuous reactor: Effect of the operating parameters. Bioresour. Technol. 2015, 191, 426-432. [CrossRef]

86. Selvaratnam, T.; Reddy, H.; Muppaneni, T.; Holguin, F.; Nirmalakhandan, N.; Lammers, P.J.; Deng, S. Optimizing energy yields from nutrient recycling using sequential hydrothermal liquefaction with Galdieria sulphuraria. Algal Res. 2015, 12, 74-79. [CrossRef]

87. Wang, S.; Zhao, S.; Cheng, X.; Qian, L.; Barati, B.; Gong, X.; Cao, B.; Yuan, C. Study on two-step hydrothermal liquefaction of macroalgae for improving bio-oil. Bioresour. Technol. 2021, 319, 124176. [CrossRef] [PubMed]

88. Hongthong, S.; Raikova, S.; Leese, H.S.; Chuck, C.J. Co-processing of common plastics with pistachio hulls via hydrothermal liquefaction. Waste Manag. 2020, 102, 351-361. [CrossRef] [PubMed]

89. Arun, J.; Gopinath, K.P.; Rajan, P.S.S.; Marudai, J.M.; Vargees, F. Co-liquefaction of Prosopis juliflora with polyolefin waste for production of high grade liquid hydrocarbons. Bioresour. Technol. 2019, 274, 296-301. [CrossRef] [PubMed]

90. Seshasayee, M.S.; Savage, P.E. Synergistic interactions during hydrothermal liquefaction of plastics and biomolecules. Chem. Eng. J. 2021, 417, 129268. [CrossRef]

91. Chen, W.T.; Jin, K.; Wang, L.N.H. Use of Supercritical Water for the Liquefaction of Polypropylene into Oil. ACS Sustain. Chem. Eng. 2019, 7, 3749-3758. [CrossRef] 